\title{
A Study on Emerging Methods and Ways in Agricultural Sciences: with Reference to Organic Farming
}

\author{
P. K. Paul ${ }^{1}$, R. R. Sinha ${ }^{2}$, A. Bhuimali ${ }^{3}$, P. S. Aithal ${ }^{4}$ and Ricardo Saavedra ${ }^{5}$ \\ ${ }^{1}$ Executive Director, MCIS, Department of CIS, Information Scientist (Offg.), Raiganj University, India \\ ${ }^{2}$ Pro Vice-Chancellor (Asian Region), Commonwealth Vocational University, Kingdom of Tonga, Oceania \\ ${ }^{3}$ Vice-Chancellor, RaiganjUniversity, West Bengal, India \\ ${ }^{4}$ Vice-Chancellor, Srinivas University, Karnataka, India \\ ${ }^{5}$ Director \& Chair, International Inter-University Programs, Azteca University, México, North America \\ E-mail: pkpaul.infotech@gmail.com
}

\begin{abstract}
Agricultural Sciences is an Applied Science but has its touch with social science due to its nature. It uses various kinds of tools, techniques, procedure, methods, principles of science; that is responsible for the cultivation of plants, crops, vegetables, livestock as well as animals. Agriculture is dedicated to the sedentary human civilization and by this people can meet their food demand. As far as the history of agriculture it is noted that agriculture as a concept emerged thousands of years before about 105,000 years ago and regarding the nascent farmers, it was about 11,500 years ago. Initially, animals were not considered within this but gradually various animals such as pigs, sheep and cattle became part of agricultural sciences since 10, 000 years ago. Farming normally considered as the cultivation in a small area whereas Agriculture is treated for a large area with huge place and expenditure. In today's context, about 11 regions of the world are cultivating commercially. Agriculture as an interdisciplinary field is concerned with various disciplines and subjects; and this trend is growing rapidly. There are diverse areas and emerging nomenclatures emerged in Agriculture viz. Chemical Agriculture, Green revolution \& Agriculture, Genetic engineering-based Agriculture, Organic Agriculture /Farming, Corporate Agriculture /Farming, Vertical Farming /Agriculture, etc.This paper is theoretical and empirical in nature. It analyzed various aspects of agriculture with special reference to the aspects, features, role, and emergence of three emerging types of agriculture viz. Organic Agriculture.
\end{abstract}

Keywords:Agriculture, Agricultural Sciences, Organic Farming, Cultivation, Emerging Agriculture, Vertical Agriculture, Corporate Agriculture

\section{I.INTRODUCTION}

The term agriculture denotes the commercialization of cultivation and farming of different items viz. corps, vegetables, plants, trees, seeds including various kinds of animals and normally it is conducted in a large place. Apart from the mentioned above, it also deals with the farming/ cultivating of fertilizers of a different kind, animal hides, leather items, chemicals-based items sugar, alcohol fibers (cotton, wool, and silk), etc. In the contemporary period, agriculture also consists of items such as biomass, biodiesel, nursery plants, fish and sea fruits and animals,etc. The aspects of biopharmaceuticals, tobacco, in legal and illegal form, both considered as Agriculture. The process of practicing of cultivation regarding the improvement of farming as well as cultivating is also called as agriculture. Agricultural Sciences is an interdisciplinary field and consist of biology, management and economics, horticulture, forestry,etc as well. Farming conducted in a small area with limited input, budget and family requirement based in some contextthoughagriculture is commercial intensive in a large place with the cultivation of the animals and by the uses of different kind of methods, products and tools is called Industrial Agriculture [1], [3], [18].Agricultural practices bring many new concepts and types inthe recent past and some of them are mentioned below, in brief.

\section{A. Agricultural Chemistry}

Uses various kinds of chemical fertilizer, insecticides, and chemical fungicides in farming, cultivation and agricultural activities. Moreover, soil make ups as well as analysis of agricultural products are also treated as Agricultural Chemistry. Green Agriculture is another agriculture and initiated and practiced in the western world by the introduction of the green revolution. Then this was spread all over the world. In recent past agriculture noted with many other aspects in farming and cultivation viz. hydroponics, plant breeding, hybridization, gene manipulation, soil nutrients, weed control, etc. Genetic Engineering is an applied science and engineering, also played a great role in developing agricultural seeds, crops, plants, vegetables, etc including the household animal production using the genetic engineering methods and procedure and this is called as Genetic Engineering based Agriculture,etc [2], [8], [10].

\section{B. Organic Agriculture}

Is another one new agricultural/ cultivation method which does not use any kind of chemical for the production viz. pesticides, fertilizers, antibiotics, growth hormones, etc. This alternative agricultural has started its rapid agro 
production practices in the twentieth century. It is a fact that internationally more than 70 million hectares land using this agriculture system. Corporate Agriculture or Farming is another emerged agricultural system that is practiced ina business context and with huge places. This kind of agriculture was normally practiced by the mega and large corporations including large-scale farms. Corporate Agriculture is practiced keeping in mind direct or immediate profit and business. However, another emerging method of Agriculture is Vertical Agriculture or Farming. Inthis method or type of agriculture crops and plants, desired agro items vertically in the stacked layers and places. Hence it isa kind of environment agriculture; and can be conducted in a place as well. It uses the soilless farming techniques and even may be conducted in a building floor or commercial complex or residential complex, etc [4], [15], [25].

\section{OBJECTIVES}

This paper is conceptual and rhetorical in nature and mainly deals with following aim and objective (but not limited to the following)

1. To know about the basics of Agricultural Sciences, including its evolution and interdisciplinary areas.

2. To learn about the emerging types of Agricultural Science, briefly.

3. To learn about the knowledge on basic features and nature on Organic Farming or Agriculture.

4. To know about the advantages, roles and growing importance of the on Organic Farming or Agriculture.

5. To get the aspects of the issues, limitation and challenges of the Organic Farming or Agriculture in developing countries and also in India.

\section{ORGANIC FARMING \& AGRICULTURE}

According to the United States Department of Agriculture (USDA) study team "organic farming is a system which avoids or largely excludes the use of synthetic inputs (such as fertilizers, pesticides, hormones, feed additives, etc) and to the maximum extent feasible rely upon crop rotations, crop residues, animal manures, off-farm organic waste, mineral grade rock additives and biological system of nutrient mobilization and plant protection”.

Organic Farming/ Agriculture is not so new and started even from ancient times. Organic Agriculture primarily concerned with the highest growth in a limited land and deals with the raising of the crops without chemicals and keeps also soil alive. It uses organic wastes to cultivation including biological materials, etc. Hence it promotes sustainable agricultural production and helps in promoting pollution free environment. According to Food and Agriculture Organization(FAO) "Organic agriculture is a unique production management system which promotes and enhances agro-ecosystem health, including biodiversity, biological cycles, and soil biological activity, and this is accomplished by using on-farm agronomic, biological and mechanical methods in exclusion of all synthetic off-farm inputs”. Organic farming avoids as well as excludes the application of the synthetically integrated chemical in the agricultural systems and cultivation viz. fertilizers, pesticides, genetically prepared organisms, etc. The basic organic farming system is time consuming and thus with the uses of following methods, the amount may be enhanced

1. Uses in rotation in the crop.

2. $\quad$ Proper and continuous crop residues.

3. Uses of proper and appropriate animal manures.

4. Legumes and similar plants.

5. Proper green manures.

6. Off farm organic wastes.

7. Uses of biofertilizers.

8. Uses of Mechanical Systems, scientifically in the cultivation, etc.

In addition to the above, in Organic farming the uses of mineral bearing rocks, applications of the biological controlling in soil productivity, controlled insect,etc are important. In another context, Organic farming is responsible for the enhancement of farm productivity; it also helps in repairing of the old environmental damage and helps in improved food security in many contexts [6], [16], [20]. Organic farming can boost or help in lack of interest in farming and cultivation due to its wider benefits; and helps in promoting of theself-sufficiency and/ or food security. A large amount of chemical fertilizers, as well as toxic pesticides, makes harmful land as well water heavily and these may lead the loss of topsoil, soil fertility, and disadvantages in surface including groundwater, loss of genetic diversity, etc and in this context Organic farming is very important and valuable in a different context.

According to the research and study, it is noted that organic farming is e even responsible for producing higher yields than that of conventional methods, in some context. Practically, this kind of farming becomes holistic production management and ultimately helps in diverse areas mentioned above and further is mentioned in Fig: 1.

The soil health (viz.with nitrogen mineralization potential and microbial abundance) can also improve by organic farming and it is ultimately resulted in lower insect and disease incidence, than traditional agriculture. This kind of agriculture system normally suitable in small-scale but compact farming has its potential in the rural areas. Hence helpful in enhancing the economic benefits as well [5], [9], [26].

\section{A. Organic Farming\& Principles}

Organic Farming is an important and healthy farming and cultivation method, it is helpful in the diverse areas and according to the experts among its principles, the following may be considered as important and valuable viz. 


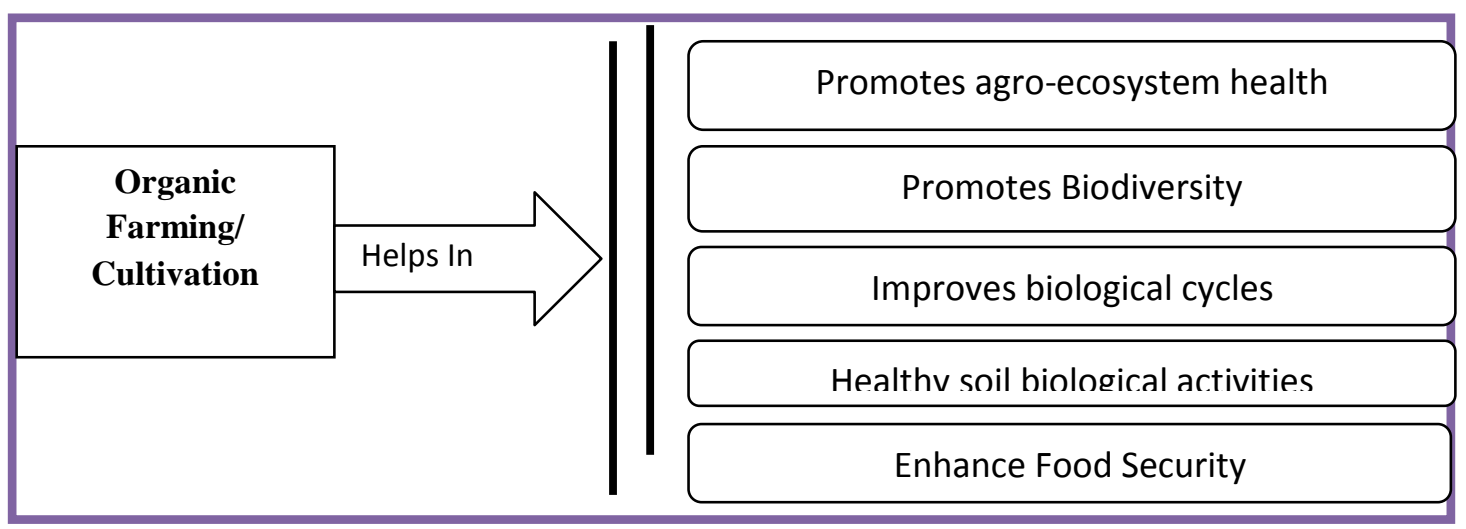

Fig.1 The sustainable benefits of Organic Farming

\section{B. Principle of Health}

Organic Farming is helpful in promoting health of diverse components and stakeholders viz. soil, plants, users of the products, animals event society and earth at a large. Hence it is a mental, physical, ecological and social wellbeing. It is responsible for the dedicated pollution free and nutritious foods for the human being [11], [17], [27].

\section{Principle of Fairness}

Organic Farming also holds the principle of Fairness. It is dedicated to the maintaining of equity for the planet and humans including other living beings. It is also good for the enhancing quality of health and economically empowered by reducing poverty. It is responsible for the balanced and fair uses of agro products.

\section{Principle of Ecological Balance}

This kind of farming is based on or modeled in the living ecological systems and thus in the ecological balancing as well as cycles in nature. Hence it is worthy of sustainable development as well.

\section{E. Principle of Care}

Organic Farming is responsible for the dedication in the caring of present and future generations by providing natural agro products and helps in food security. Further, it also cares about environment and ecology, at large.

\section{NATURE AND CHARACTERISTICS OF ORGANIC FARMING}

Organic Farming is based on following nature and characteristics (but not limited to the)

1. Organic Farming helps in long term fertility of soil including its levels, improves soil biological activities including careful mechanical systems in farming, if/ once required.

2. The farming is normally done by the natural methods, tools, and components without any kind of chemical, etc [7], [14], [19].

3. It helps in the nitrogen self-sufficiency including the effective organic materials recycling and livestock manures strongly.

4. Weed disease and pest control, etc doe by the natural means using organic maturing, biological and chemical intervention, etc.

5. Organic Farming comes with the caring benefits to the human being, animals and wider environment including wildlife, natural habitats, etc.

6. Organic Farming may be conducted in a small place or areas hence helpful for the locality and community of different parts of the globe.

7. It deals with all the features and functions of the environment supported and sustainable agriculture [12], [27], [30].

\section{NEED, IMPORTANCE AND VALUES OF ORGANIC AGRICULTURE}

Organic Farming is most emerging agricultural methods and way for farming as far as sustainable farming is concerned. It holds various direct and indirect benefits and as a result it is required by the human being for the natural food solutions and helps in ecological development. Organic Farming is the need of hour for keep continuing Green Revolution and helps in economic conditions of the society. Hence it helps in improving job opportunities. On other hand, it helps in improving the food security as well sustainable manner. Due to the increasing population growth worldwide, there are shortage of land and quality food products [13], [24], [29].

With the initiation of the Organic Farming such problems can be solved by different means. Hence the Organic Farming comes with following advantages viz. 
1. Organic Farming helps in building and enhancing the environment health for different reasons with special reference to the reduction of the level of pollution.

2. Organic Farming helps and keeps healthy health of the human as well as animals due to the reducing the level of residues in the product and following natural products and avoiding chemical, pesticides etc.

3. With the initiation of the Organic Farming it will bring more agricultural production and with appropriate sustainable level.

4. The cost of agricultural production, mainly preproduction activities. It also helps in improvement of the quality of the soil as well.

5. In this kind of agriculture only required amount of natural resources are used and that is also for the short-term benefit. Hence it is helpful in conserving and protecting for the future generation.

6. Organic Farming also helps and saves energy for the human and for the animal and machine as well.

7. Organic Farming also responsible for the reducing of the risk of crop failure, nicely.

8. The soil physical properties normally enhance with Organic Farming including water-holding capacity. Hence indirectly responsible for the reduction of the erosion [10], [21], [28].

9. The chemical properties of the soil will also enhance with the practice of Organic Farming and helps in minimizing the nutrient loss into water bodies etc.

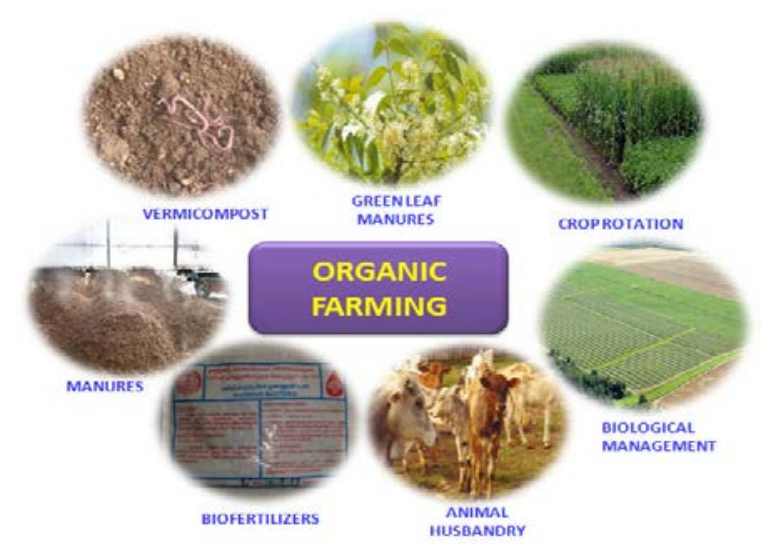

Fig.2 Organic farming vis-à-vis requirement

\section{A. Nutrient Management in Organic Farming}

As Organic Farming is promoting the natural ingredients and thus helps in promotion of the soil health by different means, as already specified. Further, with this practice the nutrition become good. Different kind of soil enhancing methods viz. green manuring and addition of manures, use of biofertilizers uses may help in build-up soil fertility. And this ultimately helps in different nutrients to the soil and enhances soil organic aspects. Soil with high organic causes less erosion, keeps water level better and thus needed in less irrigation. Soil's pH balance will also be good with healthy soil practice. Here moreover, cultivators make compost from animal manures and maintaining a good internal temperature $\left(130^{\circ}-140^{\circ} \mathrm{F}\right)$; which helps in killing unwanted bacteria and additionally organic fertilizers, bacterial and fungal biofertilizers helps by different means [3], [22].

\section{B. Weed Management}

In this kind of agricultural methods, there are no uses of chemical herbicides; as a result, with this weeding is possible manually. Furthermore tillage, flooding, mulching, etc are useful to manage the weeds. Even the pathogen methods are also useful. Weeds growth may be minimizing the uses of drip irrigation, etc.

\section{Insect Pest Management}

The availability of pest in such kind of farming is anticipated in advance. Thus, the planting schedules may be adjusted for the avoiding of serious pest related problems. It is worthy to build up a population of beneficial insects, i.e. the feed off the eggs of pests. Moreover, the uses of natural or organic insecticides like neem pesticides can be used. Here organic pesticides with low toxicity may be used to protect the people and animals. In this context, the criteria of National Organic Standards may be followed [5], [7], [23].

\section{Diseases Management}

Plant diseases are major problem in quality and quality but with proper fertility management this is can be managed. Here adoption of crop rotation may help in reduction of crops diseases in certain cases. Thus, here in organic farming beneficial organisms must be followed. Here healthy microbes, fungi and bacteria keep away the harmful bacteria, etc and helps in diseases management in organic farming as well.

\section{LIMITATIONS, CHALLENGES\& SUGGESTION IN ORGANIC FARMING: INDIA CONCERNS}

Organic Farming though offers various kinds of benefits and advantages. However, it holds some of the obstacle, problems, limitations, issues and concern and among such few important are mentioned as follows-

1. Organic manure is very good for this kind of agricultural system however this is not available so much. On the other hand, plant nutrient is very much costly and more expensive than that of chemical fertilizers.

2. Initially Organic Farming may not give good results in quantity and production. Hence here the farmer to deal with this either by compromise or by the low/high rated products.

3. Organic Farming deals with various kinds of norms, guidelines, and instruction viz. in the organic processing, maintenance, and further transportation and these are important challenges. Even certification of Organic Farming is beyond the common 
understanding of ordinary farmers or less knowledgeable or skilled farmers. As far as Indian farmers are concerned, these are many be common for many of those.

4. Marketing of the products by Organic Farming is not in general or streamlined. Hence this skill is important and needs to gather by the cultivators.

5. Further, there are many firms in India and in other parts which are not so well in chemically managed / cultivated in organic farming.

6. Even there should be proper boundaries of organic cultivation zones, etc for cultivating a million acres of land, which are still lacked due to many reasons.

7. The lack of knowledge in the certification of Organic Farming is difficult for many farmers and particularly for the Indians.

8. Lack of funds for initial and further operation of Organic Farming is an important and valuable challenge.

In a country like India, all such are common issues. Further more, the application of chemical fertilizers in India always low, hence it is possible to develop "relatively organic" farming. And even a portion of the cultivating lands may be used in organic farming.

Export of organic foods and fruits,etc can be a great deal to abroad, though there is a gap or lack of attention in this context. However proper strategies need to be adopted viz. which product to grow? the market or suitable place to sell, proper and healthy distribution channels, gear-up with the strategies to on the issue of competition, marketing policies, etc. More on awareness, certification, fund and budget, postproduction related issues are essential for its better implementation and process.

Even for more growth in Organic Farming throughout the nation as well as other countries it is expected to declare Organic Zones/ Territories/ States/ Special Export Zones etc. In India, few states already have taken the initiative in this regard viz. Uttaranchal, North-eastern states. To be a great service provider in organic foods proper steps are highly required by different sorts and authorities [6], [19]. The fulfilment of the world's hungry and poor related aspects, food security management, right policies, public and private initiatives, and technologies are highly required.

Because of organic farming does not depends on synthetic chemicals and uses natural, biological methods; therefore, proper steps must be followed. Multiple cropping is possible in organic farming thus it helps in ecology, biodiversity and brings a healthy farming system. Whereas in traditional agro based systems mono cropping that damages the soil fertility. In this context, keep such tradition are important and required to maintain always.

\section{CONCLUSION}

The agricultural system is a kind of cyclic activities deals with natural sources. Today different aspects and requirements are there for growing agriculture viz. equipment, fertilizers, pesticide, and hybrid, etc. The uses of chemical fertilizers and pesticides are increased in the recent past in agricultural production. And this will affect different aspects viz. soil, groundwater, air, human health, and environment, etc. Hence in this context of saving human beings and animals, organic manures and manure crops are suitable. In Organic farming, these are practices to get a higher amount of development which also helps in environmental benefits. Organic fertilizers and their impacts are noticeable. Apart from different traditional agro ways, technology particularly computing can be a good tool, here computer algorithms may play a major role in the field of farming to save and support ecology. Mainly the optimization algorithms may be used to help in the usage of fertilizers as well as organic manures scientifically. By ignoring the limitation and proper steps the organic farming can be more growing and natural, sustainable to us!

\section{REFERENCES}

[1] A.Z.Abbasi, N.Islam and Z.A. Shaikh,” A review of wireless sensors and networks' applications in agriculture," Computer Standards \& Interfaces, Vol. 36, No.2, pp. 263-270, 2014.

[2] W.Bond and A.C. Grundy, "Non-chemical weed management in organic farming systems,” Weed research,Vol. 41, No.5, pp.383-405, 2001.

[3] T.Cacek and L.L. Langner, “The economic implications of organic farming," American Journal of Alternative Agriculture, Vol.1, No.1, pp. 25-29, 1986.

[4] I. Darnhofer,W. Schneeberger and B.Freyer, "Converting or not converting to organic farming in Austria: Farmer types and their rationale,” Agriculture and human values, Vol. 22, No.1, pp. 39-52, 2005.

[5] I.Darnhofer,T. Lindenthal,R. Bartel-Kratochvil and W. Zollitsch, "Conventionalisation of organic farming practices: from structural criteria towards an assessment based on organic principles,” A review. Agronomy for sustainable development, Vol. 30, No.1 , pp. 67-81, 2010.

[6] A.Gattinger,A. Muller, M. Haeni, C. Skinner, A. Fliessbach, N. Buchmann and U.Niggli, "Enhanced top soil carbon stocks under organic farming,"Proceedings of the National Academy of Sciences, Vol. 109, No. 44, pp.18226-18231, 2012.

[7] Genius, Margarita, Christos J. Pantzios and Vangelis Tzouvelekas, “ Information acquisition and adoption of organic farming practices," Journal of Agricultural and Resource Economics, Vol.31, No.1, pp. 93-113, 2006.

[8] N.Gunapala and K.M. Scow, “ Dynamics of soil microbial biomass and activity in conventional and organic farming systems," Soil Biology and Biochemistry, Vol. 30, No. 6, pp. 805-816, 1998.

[9] D.G.Hole, A.J. Perkins, J.D. Wilson, I.H. Alexander, P.V. Grice and A.D. Evans, "Does organic farming benefit biodiversity?," Biological conservation, Vol.122, No.1, pp.113-130, 2005.

[10] H. Kirchmann and L. Bergström, “ Do organic farming practices reduce nitrate leaching?,” Communications in soil science and plant analysis, Vol. 32, No .(7-8), pp. 997-1028, 2001.

[11] P. Mäder, A. Fliessbach, D. Dubois, L. Gunst, P. Fried and U. Niggli, , “ Soil fertility and biodiversity in organic farming," Science, Vol. 296 , No.5573, pp. 1694-1697, 2002.

[12] J.Michelsen,"Recent development and political acceptance of organic farming in Europe,” Sociologia ruralis, Vol. 41, No.1, pp.3-20, 2001.

[13] K.M. Murphy, K.G. Campbell, S.R. Lyon and S.S. Jones, “ Evidence of varietal adaptation to organic farming systems,” Field Crops Research, Vol.102,No.3, pp.172-177, 2007.

[14] F.Oehl, E. Sieverding, P. Mäder, D. Dubois, K.Ineichen, T. Boller, and A. Wiemken, "Impact of long-term conventional and organic farming on the diversity of arbuscular mycorrhizal fungi”, Oecologia, Vol. 138, No.4 , pp. 574-583, 2004. 
[15] S. Padel, "Conversion to organic farming: a typical example of the diffusion of an innovation?," Sociologia ruralis, Vol.41, No.1, pp. 40-61, 2001.

[16] X.P. Pang and J. Letey, “ Organic farming challenge of timing nitrogen availability to crop nitrogen requirements," Soil Science Society of America Journal, Vol. 64, No.1, pp. 247-253, 2000.

[17] Pau1 , Prantosh Kumar Minakshi Ghosh and Dipak Chaterjee, "Information Systems \&Networks (ISN): Emphasizing Agricultural Information Networks with a case Study of AGRIS," Scholars Journal of Agriculture and Veterinary Sciences, Vol. 1 , No. 1, pp. 38-41, 2014.

[18] Paul and Prantosh Kumar, "Information and Knowledge Requirement for Farming and Agriculture Domain.International Journal of Soft Computing Bio Informatics, Vol. 4 , No. 2, pp. 80-84 , 2013.

[19] Paul and Prantosh Kumar etal, "Agricultural Problems in India requiring solution through Agricultural Information Systems: Problems and Prospects in Developing Countries," International Journal of Information Science and Computing, Vol. 2, No. 1, pp.3340, 2015.

[20] Paul and Prantosh Kumar etal, " Information and Communication Technology and Information: their role in Tea Cultivation and Marketing in the context of Developing Countries-A Theoretical Approach. Current Trends in Biotechnology and Chemical Research.,Vol . 5 , No. 2, pp.155-161, 2015.

[21] J.Peigné, B.C. Ball, J. Roger-Estrade and C.J.S.U. David, "Is conservation tillage suitable for organic farming? A review," Soil use and management, Vol. 23, No.2, pp. 129-144, 2007.
[22] K.S .Pietola and A.O. Lansink, "Farmer response to policies promoting organic farming technologies in Finland," European Review of Agricultural Economics, Vol. 28, No. 1, pp. 1-15, 2001.

[23] P. Ramesh, M.Singh and A.S. Rao, “ Organic farming: Its relevance to the Indian context,”Current Science, Vol. 88, No .4, pp. 561-568, 2005.

[24] P. Ramesh, N.R. Panwar,A.B. Singh, S. Ramana, S.K. Yadav, R. Shrivastava and A.S. Rao, "Status of organic farming in India", Current Science, pp. 1190-1194, 2010.

[25] E.A.Stockdale,M.A. Shepherd, S. Fortune, and S.P. Cuttle, "Soil fertility in organic farming systems-fundamentally different?," Soil use and management, Vol. 18, pp. 01-308, 2002.

[26] M.Stolze and N. Lampkin, " Policy for organic farming: Rationale and concepts,” Food Policy, Vol. 34, No. 3, pp.237-244,2009.

[27] H.Tovey, "Food, environmentalism and rural sociology: on the organic farming movement in Ireland," Sociologia ruralis, Vol. 37, No. 1 , pp. 21-37, 1997.

[28] A.Trewavas, “ Urban myths of organic farming," Nature, Vol .410, No.6827, 409, 2001.

[29] H.L.Tuomisto, I.D. Hodge, P. Riordan and D.W. Macdonald, "Does organic farming reduce environmental impacts?-A meta-analysis of European research. ,"Journal of environmental management, Vol. 112, pp. 309-320, 2012.

[30] C.A.Watson,D. Atkinson, P. Gosling,., L.R. Jackson and F.W. Rayns, " Managing soil fertility in organic farming systems," Soil use and management, Vol. 18, pp. 239-247, 2002. 